Copyright (C) 2014 by Academic Publishing House Researcher

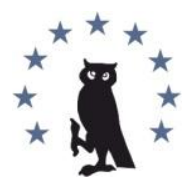

Published in the Russian Federation

European Researcher

Has been issued since 2010.

ISSN 2219-8229

E-ISSN 2224-0136

Vol. 83, No. 9-2, pp. 1677-1681, 2014

DOI: 10.13187/er.2014.83.1677

www.erjournal.ru

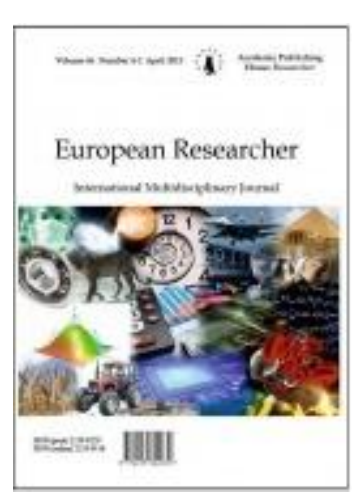

\title{
Studies on the Analgesic Potential of leaf Extracts of Allium humile on Swiss albino mice
}

\author{
${ }^{1}$ Kamini Singh \\ ${ }^{2}$ Raveesh Kumar Gangwar \\ 3 Garima Singh \\ 4 Vikash S. Jadon \\ ${ }_{5}^{5}$ Shashi Ranjan
}

${ }^{1}$ Institute of Biomedical Sciences and Research, India

Department of Biotechnology

E-mail: kaminipkv@gmail.com

${ }^{2}$ College of Agriculture, Sardar Vallabhbhai Patel University of Agriculture \& Technology Meerut, India

Departments of Entomology

E-mail: raveeshgangwar@yahoo.com

3 Lucknow University, India

Department of Plant Sciences

E-mail: sneha.garimao78@gmail.com

Institute of Biomedical Sciences and Research, India

${ }_{4}^{4}$ Assistant Professor, Department of Biotechnology

E-mail:pradeepkv5@gmail.com

5 Institute of Biomedical Sciences and Research, India

Department of Biotechnology

E-mail: shashiranjan16@gmail.com

\section{Abstract}

Allium humile is a medicinal plant found at the Alpine Himalayas of Uttarakhand at altitute of 2500-3000 meters height of sea level. In India, Allium humile, is used by local people as a spice and in ethano-medicine. In the present study, Allium humile leaves were explored for their analgesic potential on experimental model and compared to standard drugs. Allium humile at the doses of $100 \mathrm{mg} / \mathrm{kg}$ and aspirin $25 \mathrm{mg} / \mathrm{kg}$ exhibited significant (p>0.05) inhibition of the control writhes at the rate of $64.25 \%, 44.54 \%, 44.54 \%$ and $59.89 \%$ respectively when compared to that of control. Thus, methanolic extract of the plant can be fully explored for its analgesic potential which has not been reported so far. The plant extract showed a relative low toxicity hence justifies the folkloric use of plant by the local people in Western Himalayan region for curing inflammation and painful conditions.

Keywords: Allium humile; analgesic activity; Phytochemical screening. 


\section{Introduction}

India a country of immense biotic wealth and most of the plant used as medicine in ancient times, it is reported that about more than 7000 plant species used for medicinal purposes most of which are being exploited recklessly of drugs. It will be prudent to study species of indigenous medicinal and commercially valuable plants. The use of traditional medicine and medicinal plants in most developing countries, as a normative basis for the maintenance of good health has been widely observed. However, information on the uses for plants for medicine is lacking from many interior areas of Himalayan regions in India. Utilization of plants for medicinal purposes in India has been documented long back in ancient literature. However, organized studies in this direction were initiated in 1956 and off late such studies are gaining recognition and popularity due to loss of traditional knowledge and declining plant population.

Drugs which are in use presently for the management of pain and inflammatory conditions are eithernarcotics or non-narcotics (NSAIDS) and present well known side and toxic effects (Dharamsiri, J.R., et. al,. 2003; Kumara, N.K.V.M.R., 2001; Park, J.H., et. al., 2004). On the contrary herbal medicines with good absorption, less toxicity and easy availability have been used since long (Li, R. W., et. al., 2003). It is therefore essential that efforts should be made to introduce new medicinal plants to develop cheaper and effective drugs (Duffy, J.C., et. al., 2001; Ikram, M., 1983). Plants represent still a large untapped source of structurally novel compounds that might serve as lead for the development of novel drug (Moody, J. O., et. al., 2006).

Allium humile is a nutritionally functional food used for aroma and a source of physiologically beneficial and noninvasive medicines. Many pharmaceutical substances with potent and unique health-enhancing properties have been reported from other Allium species distributed worldwide. Allium humile is hardy to zone o. The flowers are hermaphrodite (have both male and female organs) and are pollinated by bees, insects etc. It is mainly found at the height of 25003000 meters of Alpine Himalayas of Uttarakhand, India near moist rock, dry rock and steep slope with a strong preference of sunny site. The plant prefers light (sandy) and medium (loamy) soils and requires well-drained soil. The plant prefers acid, neutral and basic (alkaline) soils. It cannot grow in the shade. Edible plant part used induced flowers; leaves; root. Bulb (raw or cooked), leaves (raw or cooked) are dried and used as a flavoring, while raw flowers are used as a garnish on salads. Although no specific mention of medicinal uses has been for this species, member of this genus are in general very healthy additions to the diet. They contain sulphur rich compounds with antianalgesic antioxidant, antiinflammatory, and antimicrobial properties. Thus, in the present study attempts were made to investigate its analgesic potential with a view of justifying the use of this plant in treatment of analgesic disease locally.

\section{Materials and methods}

\section{Collection of Plant Materials}

Whole plant of Allium humile was collected from various parts of Uttarakhand, India during August to September 2008. The seed samples were submitted for conservation at National Gene bank, National Bureau of Plant Genetic Resources, Pusa Campus, New Delhi, India and the national identity number (SR-01-IC 567645) was obtained. The leaves of this plant were dried under shade at $27^{\circ} \mathrm{C}$ to $30^{\circ} \mathrm{C}$ for 15 to 30 days, after which the leaves of the plant were chopped and grounded into coarse powder.

\section{Preparation of Plant Extract}

The coarse powder of material (200g) was successively extracted with solvents in order of increasing polarity like petroleum ether, chloroform, methanol and water using hot sox let extractor. The resulting extracts were concentrated by vacuum evaporator keeping the maximum temperature $48^{\circ} \mathrm{C}$ to $50^{\circ} \mathrm{C}$.

\section{Phytochemical Screening-}

The presence of various phytochemical constituents in the extract was determined using standard screening tests (Edeoga, H.O., 2005) 


\section{Experimental Animals}

White Swiss Albino Mice (20-30g) were used for this study. The animals were obtained from the animal house of the Department of Pharmacy, Sardar Bhagwan Singh (P.G) Institute of Biomedical Sciences and Research, Dehradun, Uttarakhand, India. The animals were maintained under standard environmental condition and had free access to food and water before administration of plant extract.

\section{Anti-analgesic Activity}

Six groups of white mice weighing 20-30 gm, of either sex or each group containing six mice were chosen for the study. One group was kept as control and another group was treated with the standard drug (aspirin). The extracts (Saline, Aspirin, Pet. Ether, and Methanol) were given to the rest of the groups.

The method employed was that of acetic acid induced writhing method in mice. The standard and extract were administered at a dose of $1 \mathrm{ml} / \mathrm{kg}$ and $25 \mathrm{mg} / \mathrm{kg}$ respectively all the test extract and standard were dissolved in tween 80 , boiled and cooled water.

The animals were tested for $16 \mathrm{~h}$ prior to the treatments. One hour after treatment, the control group of mice was administered $1 \mathrm{ml} / 100$ gm of normal saline and after this $1 \%$ acetic acid solution was injection at a dose level of $1 \mathrm{ml} / 100$ gm intraperitonially of body weight. Next the animals were placed individually under glass jar for observation. The number of abdominal constriction (writhing) and stretching with a jerk of himb was counted between 5 and 15 minutes after acetic acid injection.

The second group of animal was injected aspirin $(25 \mathrm{mg} / \mathrm{kg})$. Fifteen minutes later they were administered acetic acid solution as in control group. Rest group of animal were inject test extract (saline, aspirin, pet. ether, methanol) at a dose of acid solution. The onset of writhing response was observed and continued for fifteen minutes, were recorded. The response of the extract and aspirin treated group were composed with those of the animal in the control group (o.1ml saline).

Percentage protection against writhing movement (\% inhibition of writhing) was taken as an index of analgesia and it was calculated as follows:

$\%$ inhibition $=$ Wr (control) - Wr (test group) $x 100 /$ Wr (control)

Where Wr $=$ Mean Number of Writhing

\section{Statistical Analysis}

Data were expressed as mean \pm S.E. The result was statistically analyzed by the student t-test: $\mathrm{p}<0.05$ versus respective control was taken as significant.

\section{Results:}

\section{Phytochemical Screening-}

The dried leaf samples of Allium humile were subjected to extraction of active compounds with different solvents. The results of qualitative chemical investigation of these extracts have indicated the presence of following compounds that are tabulated in Table (1). All the four extracts as mentioned in table were found to possess of steroids, proteins, saponines, flavonoids, alkaloids, carbohydrates. Out of four, the aqueous extract was found to be rich in alkaloids and saponine while the petroleum ether extract was found to have a very low concentration of these compounds while the concentration of steroids was more. The methanolic extract was found to have a considerable concentration of alkaloids, saponines, and phenolic components.

\section{Anti- analgesic Activity}

The result represented in tables, shows that extracts of Allium humile at the doses of $100 \mathrm{mg} / \mathrm{kg}$ and aspirin $25 \mathrm{mg} / \mathrm{kg}$ exhibited significant ( $>0.05$ ) inhibition of the control writhes at the rate of $64.25 \%, 44.54 \%, 44.54 \%$ and $59.89 \%$ respectively when compared to that of control.

Extracts of Allium humile at the above mentioned doses, potentiated analgesic activity of aspirin shown by further decreasing the writhing response when given in combination. Statistical analysis showed that the extract of methanol showed highest analgesic potential than petroleum ether extract (Table 2) of $59.87 \%$ of inhibition as compared to the standard aspirin that gave $64.25 \%$ inhibition. The results of the present investigation indicate that the methanolic extract of Allium humile showed profound peripheral analgesic activity. The finding of this experimental 
animal study indicate that the leaf methanolic extract of Allium humile possesses analgesic ethnomedical, folkloric uses of the plant in the management and or control of painful, arthritic and other inflammatory condition in some rural communities of uttarakhand.

\section{Discussion}

The presence of alkaloids and organosulphur compounds, which has been indicated in analgesic activities, supports the traditional and local use of Allium humile. In the present study, the abdominal constriction (Writhing) model adopted is thought to partly involve local peritoneal receptors (Atta, A.H. and A. Alkofahi, 1998; Benteley, G.A., et. al., 1983; Mat Jais, A.M., et. al., 1997). The ability of the methanolic extract to cause a significant reduction in the number of acetic-acid induced writhes in mice probably suggests an anti-nociceptive property. The use of abdominal constriction (writhing) model is known to be very sensitive when compared with other models such as tail flick model (Benteley, G.A., et. al., 1983; Collier, H.O..J., et. al., 1968). This study also showed that anti-nociceptive effect of the aqueous and chloroform extract showed very less effect in same duration of time as compared to methanolic extract. The result obtained complimented the earlier investigation that methanolic extract of Allium species contains copious amount of flavonoids, organosulphur compounds (Wilson, E.A. ; B.D. Adams, 2007). Previous study on different Allium species also shows that these flavonoids and organosulphur compounds are potent analgesic and anti-inflammatory agents. This method is not only simple and reliable but also affords rapid evaluation of peripheral type of analgesic action.

\section{Acknowledgment}

The authors wish to acknowledge expressing their gratitude to The Management, Sardar Bhagwan Singh PG Institute of Biomedical Sciences \& Research, Balawala, Dehradun, India, for providing research facilities to conduct the work.

Table 1: Quantitave Phytochemical analysis of different extracts of Allium humile

\begin{tabular}{|c|c|c|c|c|}
\hline Test performed & $\begin{array}{l}\text { Petroleum } \\
\text { ether extract }\end{array}$ & $\begin{array}{l}\text { Chloroform } \\
\text { extract }\end{array}$ & $\begin{array}{l}\text { Methanol } \\
\text { extract }\end{array}$ & $\begin{array}{l}\text { Water } \\
\text { extract }\end{array}$ \\
\hline \multicolumn{5}{|l|}{ 1. Test for carbohydrates } \\
\hline i. $\quad$ Fehling' test & $(-)$ & $(+)$ & $(+)$ & $(+)$ \\
\hline Molisch's test & $(-)$ & $(+)$ & $(-)$ & $(-)$ \\
\hline Barfoed's test & $(-)$ & $(-)$ & $(-)$ & $(+)$ \\
\hline Benedict's test & $(-)$ & $(+)$ & $(+)$ & $(-)$ \\
\hline $\begin{array}{ll}\text { v. } & \text { Selivinoff's test } \\
\end{array}$ & $(-)$ & $(-)$ & $(+)$ & $(+)$ \\
\hline \multicolumn{5}{|l|}{$\begin{array}{l}\text { 2. Test for proteins and } \\
\text { amino acid }\end{array}$} \\
\hline i. $\quad$ Millon's test & $(-)$ & $(-)$ & $(-)$ & $(-)$ \\
\hline Biuret test & $(-)$ & $(-)$ & $(-)$ & $(-)$ \\
\hline iii. $\quad$ Ninhydrin test & $(-)$ & $(-)$ & $(-)$ & $(-)$ \\
\hline \multicolumn{5}{|l|}{ 3. Test for steroids } \\
\hline i. $\quad$ salkowski & $(+)$ & $(+)$ & $(+)$ & $(-)$ \\
\hline $\begin{array}{ll}\text { ii. } & \begin{array}{l}\text { Gilberman } \\
\text { test }\end{array}\end{array}$ & $(+)$ & $(+)$ & $(-)$ & $(-)$ \\
\hline iii. $\quad$ Hensen's test & $(-)$ & $(-)$ & $(+)$ & $(+)$ \\
\hline \multicolumn{5}{|l|}{ 4. Test for alkaloids } \\
\hline i. Wagner's test & $(-)$ & $(-)$ & $(+)$ & $(+)$ \\
\hline ii. $\quad$ Hager's test & $(-)$ & $(-)$ & $(+)$ & $(+)$ \\
\hline $\begin{array}{ll}\text { iii. } & \text { Mayer's test } \\
\end{array}$ & $(-)$ & $(-)$ & $(-)$ & $(-)$ \\
\hline \multicolumn{5}{|l|}{$\begin{array}{l}\text { 5. Test for phonolic and } \\
\text { flavonoid compounds }\end{array}$} \\
\hline i. $\quad$ Vanilin- HCL test & $(-)$ & $(-)$ & $(+)$ & $(+)$ \\
\hline Ferric chloride test & $(+)$ & $(+)$ & $(+)$ & $(-)$ \\
\hline $\begin{array}{lll}\text { iii. } & \text { Zinc } & \text { hydrochloric } \\
\text { acid }\end{array}$ & $(-)$ & $(-)$ & $(-)$ & $(-)$ \\
\hline
\end{tabular}




\begin{tabular}{|lllll|}
\hline \multicolumn{1}{|c|}{ reduction test } & & & \\
\hline 6. Test for tannins & $(-)$ & $(-)$ & $(+)$ & $(+)$ \\
\hline 7. Test for saponins & $(-)$ & $(-)$ & $(-)$ & $(+)$ \\
\hline
\end{tabular}

Table 2: comparative study of analgesic activity of Allium humile extracts vs. aspirin

\begin{tabular}{|llll|}
\hline Treatment & Dose & No. of writhing (mean) & Percent inhibition \\
\hline Saline (control) & $10 \mathrm{ml} / \mathrm{kg}$ & $22.83 \pm 6.08$ & - \\
\hline Aspirin & $100 \mathrm{mg} / \mathrm{kg}$ & $8.16 \pm 1.47$ & $64.25 \%$ \\
\hline Pet. Ether extract & $100 \mathrm{mg} / \mathrm{kg}$ & $12.66 \pm 2.16$ & $44.54 \%$ \\
\hline Methanol extract & $100 \mathrm{mg} / \mathrm{kg}$ & $9.16 \pm 1.72$ & $59.87 \%$ \\
\hline
\end{tabular}

*p<0.05 compared with control; student's t-test.

\section{References:}

1. Dharamsiri, J.R., A.C. Jayakodi, G. Galhena, S.S.P. Liyanage and W.D. Ratnasoriya, (2003). Antiinflammatory and analgesic activities of mature fresh leaves of Vitex negundo. Journal of Ethanopharmacology, 87: 199-206.

2. Kumara, N.K.V.M.R., (2001). Identification strategies to improve research on medicinal plants used in Sri Lanka. In: WHO Symposium. University of Ruhuna, Galle, Sri Lanka, pp: 12-14.

3. Park, J.H., K.H. Son, S.W. Kim, H.W. Chang, K. Bae, S.S. Kang and H.P. Kim, (2004). Antiinflammatory activity of Synurus deltoids. Phytotherapy Research, 18: 930-933.

4. Li, R.W., S.P. Mayers, D.N. Leach, G.D. Lin and G. Leach, (2003). A cross cultural study: Antiinflammatory activity of Australian and Chinese plants. Journal of Ethanopharmacology, 85: 25-32.

5. Duffy, J.C., J.C. Dearden and C. Rostron, (2001). Design, Synthesis and biological testing of a novel series of anti- inflammatory drugs. Journal of Pharmacy and Pharmacology, 53: 1505-1514.

6. Ikram, M., (1983). Hamdard Medicus, 26: 16-17.

7. Moody, J.O., V.A. Robert, J.D.Connolly and P.J. Houghton, (2006). Anti-inflammatory activities of the methanol extracts and an isolated furanoditerpene constituent of Sphenocentrum jollyanum Pierre (Menispermaceae). Journal of Ethanopharmacology, 104: 87-91.

8. Edeoga, H.O., D.E. Okwu and B.O. Mbaebie, (2005). Phytochemical Constituents of some Nigerian medicinal plants. African Journal of Biotechnology, 4(7): 685-688.

9. Atta, A.H. and A. Alkofahi, (1998). Anti-nociceptive and anti-inflammatory effects of some Jordian medicinal extract. Journal of Ethnopharmcology, 60: 117-24.

10. Benteley, G.A., S.H. Newton and J.B. Starr, (1983). Studies on the anti-nociceptive action of alphaagonist drugs and their interaction with optoid mechanisms. British Journal of Pharmacology, 79:125-134.

11. Mat Jais, A.M., Y.M. Dambisya and T.J. Lee, (1997). Anti-nociceptive activity of Channa striatus (haruan) extracts in mice. Journal of Ethnopharmacology, 57: 125-130.

12. Collier, H.O.J., L.C. Dinnen, C.A. Johnson and C. Schneider, (1968). The abdominal constriction response and its suppression of analgesic drugs in mouse. British Journal of Pharmacology, 32: 295-310.

13. Wilson, E.A. and B.D. Adams, (2007). Antioxidant, anti-inflammatory and antimicrobial properties of garlic and onions. Nutrition and Food Science, 37: 178-183. 